\title{
Development of a Multi-Dimensional Scale to Measure Professional Athletes as Role Models
}

\author{
Doyeop Kim', Giyong Koo², Minkil Kim², \\ Stephen Shin'3, \& Anthony Dixon' \\ ${ }^{1}$ Louisiana State University, Alexandria, LA, USA \\ ${ }^{2}$ Troy University, $A L, U S A$ \\ ${ }^{3}$ Belmont University, TN, USA
}

Received 3 July 2021 | Revised 4 September 2021 | Accepted 22 November 2021

Open Access Available online at www.johsk.com

\begin{abstract}
Previous studies have indicated that young students who play sports look up to professional athletes and perceive these athletes as their role models. However, empirical studies that examine such perceptions comprehensively have not been conducted. In order to fill this gap in the literature, the current study developed a multi-dimensional scale to measure college student athletes' attitudes toward professional athlete role models. The eight-factor sports role model scale has 40 items. The results of this study indicate that student athletes observe and emulate the eight dimensions of their sports role model's behavior on and off the court in order to become like that role model. Such findings support social learning theory in the sport management discipline.
\end{abstract}

Key words: Sport Role Model, Professional Athlete, Student Athlete, Scale Development

\section{INTRODUCTION}

With the growing popularity of professional athletes under the spotlight, many students who participate in sporting activities choose professional athletes as their role models (Kohlstrung, 2016). "When I take my kid out and hit him ground balls at shortstop, he wants to be Derek Jeter. He does not want to be me. So any professional athlete who tells you he is not a role model is full of baloney" (Pulley, 2001, p. 131). In the highly commercialized sport industry, professional athletes who receive high salaries and media attention have become role models for the younger generation (Adair, 2015). Professional athletes are expected to play an important public role due to their prominence and visibility in the media (Guest \& Cox, 2009). Leading sports stars are celebrities, and society expects them to be a public role model (Coakley, 2001; Rojek, 2006). Regarding the status of sports role models, a former NBA star, Tim Duncan, mentioned that professional athletes as role models should be careful of their behavior on and off the court (Feezell, 2005). An American Olympic gold medalist, Cheryl Miller also said, "When you reach a certain level of visibility, you are a role model whether you like it or not" (Globus, 1998, p. 28).

Journalists argue that sports role models' behavior on and off the court strongly influences college students' life in various ways (Smoll, 2015; Williams, 2017). Scholars also indicated that sports role models play an important role in helping young students develop viable self-concept (Bricheno \& Thornton, 2007; Guest \& Cox, 2009). Early adults are likely to be independent of their parents while defining and developing their self-concept (Gibson, 2003). Therefore, these young individuals seek external role models, such as highprofile athletes, through the media who can help them formulate self-concept (Strudler, 2000). These young people observe and emulate various aspects of their ideal sports role model (May, 2009). Therefore, they can become similar to their sports role model (Neemann \& Harter, 2012). Furthermore, marketing researchers indicated that as a way of becoming similar to their sports role models, college students use the same sportswear, sports shoes and products which the role models endorse (Bush, Martin, \& Bush, 2004). Marketing managers who target these young college students utilized these professional sports role models in television commercials (Clark, Martin, \& Bush, 2001).

The phenomenon of professional athletes being regarded as role models for collegiate student athletes can be explained by social 
learning theory (Bandura, 1977). Social learning theory indicates that individuals tend to observe others while formulating their own beliefs and attitudes. People learn a new skill or behavior by watching another prominent person, who thus plays an essential role in this learning and socialization process (Bandura, 1977). Such a process can be indirect, such as observing external role models through the mass media, because individuals' learning of a specific behavior is not necessarily related to the direct experience of that action (Bandura, 1977). Young students learn new skills, behaviors, or values by observing and following these vicarious role models presented by the media and reproduce them if these attributes and values become more critical to their life (Bandura, 1977).

Previous studies (Burch \& Murray, 1999; Feezell, 2005; Globus, 1998; Harris, 1994; Kellner, 1996; Simons, 1997; Wilson \& Sparks, 1996) have identified key attributes that define the concept of sports role models. The attributes include clothing styles, athletic footwear, fame, wealth, high social status, perceived positive value to society, supreme athleticism on the court, desire to win, championship, greatness throughout a career, charismatic play style, good personality, confidence, sportsmanship, fair play, community service, strong family ties, moral behaviors, hard work toward reaching a goal, dedication, commitment, love and respect for the game, and charitable work. Additionally, other studies represented several attributes of athletic role models, such as physical skills, moral behavior on and off the court, personal characteristics, interpersonal and intellectual abilities, self-actualization, giving back to society, physical characteristics, and socio-economic status (Assibey-Mensah, 1997; Bricheno \& Thornton, 2007; Fleming, Hardman, Jones, \& Sheridan, 2005; Giuliano, Turner, Lundquist, \& Knight, 2007; Guest \& Cox, 2009; May, 2009; Vescio, Wilde, \& Crosswhite, 2005). However, there has been no scientific scale to comprehensively measure all these attributes of professional sports role model.

Some existing sports role model scales have been used to measure the relationship between a general sports role model concept and sport consumer behavior. For example, Rich's (1997) five-item general role model scale, developed in the management field, has been used in sport marketing research (Bush, Martin, \& Bush, 2004). These previous studies found that sports role models influence young consumers' purchase intention and behavior. In addition, a three-item sports role model factor as part of the sports interest inventory scale (Funk, Mahony, Nakazawa, \& Hirakawa, 2001) was used in several sport consumer behavior studies (Funk, Ridinger, \& Moorman, 2003; Kim \& Trail, 2010). These findings indicated the positive relationship between sports role models and consumers' interest in and attendance at sporting events. Also, Arai, Ko, and Kaplanidou (2013) included the three-item sports role model factor in their athlete brand image scale. They found that for consumers, sports role model is positively related to athlete brand image.

However, these existing scales failed to adequately capture various dimensions of the sports role model construct, such as athletic performance, professionalism, physical appearance, personality, fame/fortune, community service, and morality. Therefore, little is empirically known about the several domains which are demonstrated by sports role models and their relationships with the learning behavior of the young admirers. Therefore, the purpose of this study was to develop and validate a valid and reliable instrument to measure various aspects of the sports role model construct for college student athletes. In order to achieve the aim of the study, this study developed a multidimensional measurement tool of the sports role model scale.

\section{METHODS}

\section{Participants}

The researchers recruited 716 student athletes from universities in the northern region of South Korea who perceive professional athletes as their role models. The researcher provided those student athletes with the information on the research purpose, the requirement for study participation, and the informed consent letter. These students participated in the study by answering the Korean version of the questionnaire. All data were analyzed as a group and stored in the password-protected computer of the primary researcher. As a way of protecting the confidentiality of the research participants, the survey questionnaire did not contain any information that personally identifies them. The results of this study are used for scholarly purposes only and shared with other researchers of the study. There were no known physical or psychological risks, inconveniences, and discomforts that the participants might experience while completing the survey questionnaire. However, if any respondent felt uncomfortable with participating in the study, he or she was able to withdraw from completing the survey at any time.

\section{Procedures}

The English version of questionnaire items was generated and developed following a comprehensive literature review of methods for measuring attributes of sports role models. In order to examine the criterion validity of this newly-developed scale (DeVellis, 2012), the questionnaire included a self-concept measure. The study adapted the self-perception scale (Neemann \& Harter, 2012), which is composed of various domains (i.e., scholastic competence, athletic competence, physical appearance, and social acceptance).

To evaluate the content validity of the sports role model scale, the questionnaire items were reviewed by a panel of five experts from departments of sport management, education, and psychology in the United States (DeVellis, 2012). Some overlapping items in terms of the athletic performance (i.e., my sports role model is a superior athlete) were removed. For the face validity of the instrument, 50 college students reviewed and responded to the items (Netemeyer, Bearden, \& Sharma, 2003).

Next, two bilingual experts translated the English version of the questionnaire into Korean. Another panel of two experts interpreted the translated Korean questionnaire back to English to verify the instrument's reliability and clarify it for the eventual survey respondents. Therefore, the initial questionnaire consisted of seven factors: athletic performance (8 items), professionalism (22 items), physical appearance ( 7 items), personality (12 items), community service ( 7 items), morality ( 7 items), and fame/fortune (7 items). 


\section{Data Analysis}

Next, the researcher randomly split this dataset into two groups, utilizing the Statistical Package for the Social Sciences (SPSS) computer program. Gorsuch (1983) asserted that at least 200 people are needed to conduct a factor analysis. An Exploratory Factor Analysis (EFA) was conducted on the 355 respondents of the first dataset to develop the initial factor structure for the sports role model scale. A Confirmatory Factor Analysis (CFA) was conducted on the 361 participant responses of the second dataset to see if any changes to this original model should be made. Such modifications of the model were based on a combination of statistical results (i.e., model fit indices) and theoretical senses. For example, the original sports role model scale was examined and revised by model fit indices, such as RMSEA, CFI, and SRMR, which are the most rigorous measures, and theoretical interpretability of items in each factor (Schumacker \& Lomax, 2010). This study utilized RMSEA, CFI, and SRMR because those fit indices that are the least influenced by sample size and parameter number. The cut-off value of RMSEA for good fit is .08; the cut-off value of CFI for good fit is .90; and the cut-off value of SRMR for good fit is .08 (Hu \& Bentler, 1999). The reliability of the modified sports role model scale was examined by the internal consistency test (i.e., Cronbach's alpha).

\section{RESULTS}

Of the 716 respondents, $72 \%$ were male and $28 \%$ were female. Ages ranged between 19 and 25. Study participants were considered to have positive perceptions of their sport role models' behavior on and off the court due to their mean score which was higher than 3.5 (the half-way point of a 7-point Likert scale) for all questionnaire items.

\section{Exploratory Factor Analysis (EFA)}

For the EFA of the first sample of 355 participants, the 70 questionnaire items were analyzed to establish an initial factor structure of the sports role model scale. The study utilized a principal-components analysis with oblique rotation, a promax rotation technique. The KMO measure for sampling adequacy was 0.96 , and the BTS value was 18,124.76 $(p<0.001)$. These figures indicate that the sample is appropriate for factor analysis. The principal-components analysis identified eight factors with 67 items, explaining $66.76 \%$ of the total variance. After careful examination of the pattern matrix, 13 of the EFA items were discarded (AP3, AP4, PRO12, PRO21, PER2, PER5, COM1, COM2, M4, M5, M6, M7, and FF1), due to the critical issue of inappropriate theoretical justification. For example, AP3 and AP4 items were supposed to be a part of the athletic performance factor. However, they belonged to another factor (i.e., professionalism). Consequently, an eight-factor model with 54 items emerged for conducting a further CFA. As stated in Table 1, the eight factors which emerged from the EFA were professionalism (18 items, $\alpha=0.95)$, personality (10 items, $\alpha=0.91$ ), fame and fortune ( 6 items, $\alpha=0.88$ ), athletic performance ( 6 items, $\alpha=0.90$ ), community service ( 5 items, $\alpha=0.91$ ), game outfit ( 3 items, $\alpha=0.87$ ), physical strength ( 3 items, $\alpha=0.82$ ), and morality ( 3 items, $\alpha=0.90$ ). This factor structure of the sports role model is almost consistent with the conceptual approaches. Six factors (i.e., professionalism, personality, fame and fortune, athletic performance, community service, and morality) were equivalent between the two models. However, physical appearance, which had been implemented, was divided into the two dimensions, game outfit and physical strength.

\section{Confirmatory Factor Analysis (CFA)}

The study used the second group of 361 participants to conduct the CFA for confirming and revising the eight-factor structure, using the 54 items of the sports role model scale established by the EFA. This study examined the initial measurement model on the basis of multiple model fit indices (i.e., chi-square fit index, RMSEA, CFI, and SRMR). The results indicated that the initial eight-factor with 54-item model did not statistically fit the current data. For example, the chi-square fit index was statistically significant $\left(X^{2}=3964.88, p<0.001\right)$ indicating that the measurement model does not fit the data. Furthermore, the CFI fit index was 0.83, which is below the cutoff value (0.90). On the other hand, the RMSEA fit index was 0.07 , which is in the acceptable model fit range (0.08). Also, the SRMR fit index was 0.06 , which is deemed acceptable.

On the basis of the model fit indices results, the study modified the initial measurement model in order to obtain reasonable model fit. As a way of respecifying the current model, the study examined whether the model had low factor loading items. After careful investigation, this study deleted 10 indicators (AP1, PRO2, PRO5, PRO8, PRO13, PRO14, PRO15, PER3, PER12, and FF4) whose factor loading was less than 0.71 . This approach is likely to increase the convergent validity of the model (Anderson \& Gerbing, 1988). Next, the CFA was conducted again; it showed that the fit indices of the modified measurement model had improved. For instance, the chi-square fit index decreased $\left(\chi^{2}=2443.16, p<0.001\right)$. Also, the CFI fit index increased to 0.88. The RMSEA fit index was the same, at 0.07. The SRMR fit index was the same, at 0.06 . In spite of the respecification, the measurement model still had four indicators (AP7, PRO1, FF3, and FF5) that had a low factor loading. Therefore, those four items were deleted. The chi-square fit index decreased $\left(\chi^{2}=1906.13, p<0.001\right)$. Also, the CFI fit index increased to 0.90, which meets the recommended threshold. The RMSEA fit index was the same, at 0.07. The SRMR fit index was the same, at 0.06 . However, the factor loading of the Fame and Fortune item $2(0.70)$ was lower than the criterion. This indicator was retained, because of its theoretical meaning, in order to create the focal construct, which should comprise at least three items. 
Table 1. Rotated Factor Pattern Matrix for Sports Role Model Dimensions ( $n=355)$

\begin{tabular}{|c|c|c|c|c|c|c|c|c|}
\hline FACTOR & 1 & 2 & 3 & 4 & 5 & 6 & 7 & 8 \\
\hline \multicolumn{9}{|l|}{ Professionalism } \\
\hline Set example (PRO1) & 0.61 & & & & & & & \\
\hline Inspire me (PRO2) & 0.47 & & & & & & & \\
\hline Work hard (PRO3) & 0.82 & & & & & & & \\
\hline Determined person (PRO4) & 0.90 & & & & & & & \\
\hline Disciplined person (PRO5) & 0.87 & & & & & & & \\
\hline Tough (PRO7) & 0.69 & & & & & & & \\
\hline Passionate (PRO8) & 0.57 & & & & & & & \\
\hline Leadership (PRO9) & 0.88 & & & & & & & \\
\hline Never give up (PRO10) & 0.75 & & & & & & & \\
\hline Brave (PRO13) & 0.40 & & & & & & & \\
\hline Fair player (PRO14) & 0.54 & & & & & & & \\
\hline Sportsmanship (PRO15) & 0.51 & & & & & & & \\
\hline Desire to win (PRO16) & 0.80 & & & & & & & \\
\hline Dedicated athlete (PRO17) & 0.80 & & & & & & & \\
\hline Love for game (PRO18) & 0.79 & & & & & & & \\
\hline Competitive (PRO19) & 0.54 & & & & & & & \\
\hline Strong work ethic (PRO20) & 0.61 & & & & & & & \\
\hline Successful player (PRO22) & 0.45 & & & & & & & \\
\hline \multicolumn{9}{|l|}{ Personality } \\
\hline Good person (PER1) & & 0.66 & & & & & & \\
\hline Personable (PER3) & & 0.53 & & & & & & \\
\hline Loving (PER4) & & 0.72 & & & & & & \\
\hline Friendly (PER6) & & 0.69 & & & & & & \\
\hline Kind (PER7) & & 0.61 & & & & & & \\
\hline Generous (PER8) & & 0.61 & & & & & & \\
\hline Trustworthy (PER9) & & 0.63 & & & & & & \\
\hline Humble (PER10) & & 0.86 & & & & & & \\
\hline Responsive to fans (PER11) & & 0.63 & & & & & & \\
\hline \multicolumn{9}{|l|}{ Fame and Fortune } \\
\hline High salary (FF2) & & & 0.84 & & & & & \\
\hline High social status (FF3) & & & 0.61 & & & & & \\
\hline Famous (FF4) & & & 0.54 & & & & & \\
\hline Affluent (FF5) & & & 0.56 & & & & & \\
\hline Luxurious home (FF6) & & & 0.93 & & & & & \\
\hline Expensive car (FF7) & & & 0.88 & & & & & \\
\hline \multicolumn{9}{|l|}{ Athletic Performance } \\
\hline Excellent player (AP1) & & & & 0.62 & & & & \\
\hline High-level performer (AP2) & & & & 0.55 & & & & \\
\hline Best player (AP5) & & & & 0.89 & & & & \\
\hline Dominate competition (AP6) & & & & 0.79 & & & & \\
\hline Charismatic play (AP7) & & & & 0.51 & & & & \\
\hline Exemplary performance (AP8) & & & & 0.61 & & & & \\
\hline \multicolumn{9}{|l|}{ Community Service } \\
\hline Giving back (COM3) & & & & & 0.53 & & & \\
\hline Help people (COM4) & & & & & 0.67 & & & \\
\hline Charitable work (COM5) & & & & & 0.75 & & & \\
\hline Donate money (COM6) & & & & & 0.78 & & & \\
\hline Community service (COM7) & & & & & 0.62 & & & \\
\hline \multicolumn{9}{|l|}{ Game Outfit } \\
\hline Clothing style (PA1) & & & & & & 0.78 & & \\
\hline Athletic apparel (PA2) & & & & & & 0.90 & & \\
\hline Athletic footwear (PA3) & & & & & & 0.90 & & \\
\hline \multicolumn{9}{|l|}{ Physical Strength } \\
\hline Physically strong (PA4) & & & & & & & 0.78 & \\
\hline Physically fit (PA6) & & & & & & & 0.53 & \\
\hline Powerful (PA7) & & & & & & & 0.62 & \\
\hline \multicolumn{9}{|l|}{ Morality } \\
\hline Honest (M1) & & & & & & & & 0.58 \\
\hline Integrity (M2) & & & & & & & & 0.57 \\
\hline Honorable (M3) & & & & & & & & 0.56 \\
\hline
\end{tabular}

The study investigated the criterion validity of the modified sports role model scale. It examined the correlation coefficients between the eight factors of the sports role model construct and the four factors of the self-concept construct (i.e., scholastic competence, athletic competence, physical appearance, and social acceptance). The results indicated that these eight factors of the sports role model construct 
are significantly correlated with the four factors of the self-concept construct. The correlation coefficients ranged from 0.20 to 0.37.

In order to verify the convergent validity of the scale, this study examined the Average Variance Explained (AVE) values of each dimension. The AVE values ranged from 0.57 to 0.74 , which meet the recommended threshold $(0.50)$. In order to verify the discriminant validity of the scale, this study tested to see if the square root of every AVE value belonging to each sub-construct is larger than any correlation among any pair of sub-constructs. The square root of all the AVE values were larger than all the correlation values among the sub-constructs, except that the correlation value between the professionalism sub-construct and the morality sub-construct was larger than the square root of the AVE value belonging to the professionalism sub-construct. The Cronbach's alpha values of all the eight factors ranged from 0.80 to 0.94 , which are above the recommended threshold $(0.70)$.

Table 2. Revised Model's $(n=361$ ) Factor Loading $(\lambda)$, Cronbach's Alpha $(\alpha)$, and Average Variance Explained (AVE)

\begin{tabular}{|c|c|c|c|}
\hline FACTOR & $\lambda$ & $\alpha$ & AVE \\
\hline Professionalism & & .94 & .61 \\
\hline Work hard (PRO3) & .82 & & \\
\hline Determined person (PRO4) & .73 & & \\
\hline Tough (PRO7) & .72 & & \\
\hline Leadership (PRO9) & .80 & & \\
\hline Never give up (PRO10) & .71 & & \\
\hline Desire to win (PRO16) & .83 & & \\
\hline Dedicated athlete (PRO17) & .79 & & \\
\hline Love for game (PRO18) & .82 & & \\
\hline Competitive (PRO19) & .83 & & \\
\hline Strong work ethic (PRO20) & .77 & & \\
\hline Successful player (PRO22) & .76 & & \\
\hline Personality & & .93 & .64 \\
\hline Good person (PER1) & .78 & & \\
\hline Loving (PER4) & .80 & & \\
\hline Friendly (PER6) & .85 & & \\
\hline Kind (PER7) & .87 & & \\
\hline Generous (PER8) & .81 & & \\
\hline Trustworthy (PER9) & .78 & & \\
\hline Humble (PER10) & .72 & & \\
\hline Responsive to fans (PER11) & .74 & & \\
\hline Fame and Fortune & & .88 & .74 \\
\hline High salary (FF2) & .70 & & \\
\hline Luxurious home (FF6) & .93 & & \\
\hline Expensive car (FF7) & .93 & & \\
\hline Athletic Performance & & .84 & .58 \\
\hline High-level performer (AP2) & .71 & & \\
\hline Best player (AP5) & .78 & & \\
\hline Dominate competition (AP6) & .78 & & \\
\hline Exemplary performance (AP8) & .76 & & \\
\hline Community Service & & .92 & .72 \\
\hline Giving back (COM3) & .82 & & \\
\hline Help people (COM4) & .87 & & \\
\hline Charitable work (COM5) & .91 & & \\
\hline Donate money (COM6) & .85 & & \\
\hline Community service (COM7) & .77 & & \\
\hline Game Outfit & & .88 & .72 \\
\hline Clothing style (PA1) & .78 & & \\
\hline Athletic apparel (PA2) & .87 & & \\
\hline Athletic footwear (PA3) & .89 & & \\
\hline Physical Strength & & .80 & .57 \\
\hline Physically strong (PA4) & .74 & & \\
\hline Physically fit (PA6) & .75 & & \\
\hline Powerful (PA7) & .77 & & \\
\hline Morality & & .89 & .74 \\
\hline Honest (M1) & .83 & & \\
\hline Integrity (M2) & .89 & & \\
\hline Honorable (M3) & .86 & & \\
\hline
\end{tabular}




\section{DISCUSSION}

This current sport role model scale has comprehensively established the eight dimensions of the sports role model construct, such as athletic performance, professionalism, game outfit, physical strength, personality, fame/fortune, community service, and morality on the basis of the rigorous scale development procedure. Therefore, this multidimensional measurement tool can be used to scientifically examine scores of the eight domains which are demonstrated by sports role models and their relationships with the learning and patronage behavior of the young admirers. On the basis of the study findings, sport role model can be defined as the construct which is composed of the eight sub-constructs and positively influences admirers' self-concept development.

Consistent with social learning theory, Korean college student athletes who participated in this study seemed to perceive and learn various on- and off-court behavior of their own professional sports role model. Furthermore, the findings of this study indicated that such perception on the multiple aspects of the sports role models can help these young college students develop the several domains of their self-concept (i.e., scholastic competence, athletic competence, physical appearance, and social acceptance) and become similar to their own sports role model who exemplifies the eight dimensions. Based on these findings, it is suggested that administrators, coaches, and athletes in the professional sport organizations acknowledge this significant role of professional sports role models on college student athletes' life.

The descriptive statistics of the preliminary factor model indicated that athletic performance had the highest mean score $(\mathrm{M}=6.36$; $\mathrm{SD}=0.73)$, whereas community service had the lowest mean score $(\mathrm{M}=5.50 ; \mathrm{SD}=1.09)$ in the Korean sample. In other words, the highest score of athletic performance might be attributable to learning by heart just for scores in Korean society. On the other hand, the possible reason for the lowest score of community service in the sample was that Korean professional athletes are little involved in the community service. Based on these findings, it is suggested that coaches and administrators in the Korean sports associations help college student athletes balance their school work and athletics, while encouraging professional athletes to give back to the community and establishing more community service programs.

The factor analysis revealed eight dimensions: professionalism, personality, fame and fortune, athletic performance, community service, morality, game outfit, and physical strength. Athletic performance was the most significant aspect that makes high-profile athletes role models. Student athletes watch and learn superior on-court performance of their sport role models to master certain sports skills and improve their athletic performance. Previous research also regarded athletic performance as one of the important domains that sports role models exhibit (Biskup \& Pfister, 1999; Bricheno \& Thornton, 2007; Feezell, 2005; Fleming et al., 2005; Freedman-Doan \& Eccles, 1996; Funk, et al., 2002; Giuliano et al., 2003; Guest \& Cox, 2009; Harris, 1994; May, 2009; Vescio et al., 2005; Wilson \& Sparks, 1996). Recently, Stephen Curry, who is widely known as the best 3-point shooter in the NBA history, has totally changed the paradigm of the modern basketball (Abbott, 2016). Many young basketball players imitate and practice Curry's prominent three-point shooting technique which led his team to the three-time championships (Abbott, 2016).

Professionalism was also regarded as one of the important dimensions. Professional athletes who work very hard every single day are perceived as good role models for the young generation. The literature supported the importance of professional athletes' professionalism (Biskup \& Pfister, 1999; Bricheno \& Thornton, 2007; Bush et al., 2004; Feezell, 2005; Fleming et al., 2005; Giuliano et al., 2003; Globus, 1998; Guest \& Cox, 2009; Strudler, 2000; Vescio et al., 2005; Wilson \& Sparks, 1996). Regardless of winning the championships, hard work and discipline which professional athletes exhibit on a daily basis can have a positive impact on young people's life. For example, Chanho Park, a former Major League Baseball (MLB) player, never gave up, continued to improve himself in spite of a series of injuries, and consequently broke the record for the most wins by an Asian pitcher with 124 (Terrill, 2012). Such self-discipline and incredible work ethic which he showed throughout his MLB career encouraged young Korean baseball players and college students to work hard (Kim, 2009).

Personality also played an important role in representing sport role models. Professional athletes who have a good personality are perceived to be good role models for young learners. Superior athletes who possess a good personality are loved and praised by many fans and the media (Eisenband, 2010). These findings were consistent with the previous studies (Bricheno \& Thornton, 2007; Fleming et al., 2005; Giuliano et al., 2003; McInerney \& McInerney, 1998; Rich, 1997; Wescio et al., 2005; Wright et al., 1997). Good relationships with family members, teammates, coaches, fans, and opponents should be one of the crucial aspects for public sports role models. On the contrary, professional athletes who show rude or violent behavior toward opposing players, coaches, and fans cannot become a good role model for young admirers in our society (Mclendon, 2016).

Engaging in community service has been established as one of the crucial qualifications for sport role models. Professional athletes pay attention to and speak up on community issues while helping people in trouble because they receive substantial media attention and arouse public interest. The literature also supported this social responsibility aspect of sports role models (Burch \& Murray, 1999; Bricheno \& Thornton, 2007; Feezell, 2005; Fleming et al., 2005; Globus, 1998; Guest \& Cox, 2009; May, 2009). Kevin Durant, an NBA superstar, recently donated $\$ 10$ million to support public schools and local students who are in need (Ellis, 2018). As such, the successful professional sports role model who contributes to the community is likely to positively influence their young admirers to work hard and succeed in their field in order to become like their role model.

Morality was also one of the essential aspects of being a good sports role model. These public sports role models should be responsible for living a moral life for their admirers. This moral aspect of sports role models is supported by the literature (Bricheno \& Thornton, 2007; Feezell, 2005; Guest \& Cox, 2009; Miller Brewing Company, 1983; Vande Berg \& Trujille, 1989; Wright, Wong, \& Newill, 1997). The media severely blame the immoral behavior of professional athletes due to their public figure status in society. For example, an NBA legend, Kobe Bryant who is the husband and father in his family was criticized by the media and lost several endorsement contracts when he committed adultery and was prosecuted for sexual assault (Tuchman \& Cabell, 2003). He apologized in public and made every effort to perform on and off the court in an excellent manner. In result, he redeemed his previous immature behavior and regained the fame as the 
superstar basketball player (Stern, 2016). Professional sports role models who live a moral life can positively influence immature admirers to become an upright and moral citizen.

Fame and fortune were identified as another significant domain. Professional athletes who earn millions of dollars receive the media spotlight and keep their celebrity status. This result was consistent with the sports literature (Assibey-Mensah, 1997; Bricheno \& Thornton, 2007; Clark et al., 2001; Fleming et al., 2005; Giuliano et al, 2003; MacCallum \& Beltman, 2002; Sinclair, 1997; Strudler, 2000; Vande Berg \& Trujille, 1989; Wilson \& Sparks, 1996). The media frequently reveal the enormous salaries, luxurious house, and expensive cars of high-profile athletes which ordinary people cannot afford to purchase in their lifetime (Badenhausen, 2018). Furthermore, professional athletes and their games are always at the center of media attention, while highly praising the superior performance in the clutches (Kell, 2016). Observing a successful career and life which their own sports role model enjoys can strongly motivate college student athletes to work hard and obtain their dream job.

However, the hypothesized physical appearance factor was further divided into two dimensions; game outfit and physical strength. This finding seems understandable. On one hand, many high-profile athletes wear their own shoes and uniform with their back number and name. College student athletes are likely to imitate the game outfit of their favorite athlete. For example, basketball players all over the world emulated Michael Jordan's long and wide shorts and jersey with an elbow band and calf sleeve, while wearing Air Jordan basketball shoes (O'Brien, 2015). Furthermore, the NBA has recently changed its basketball shoes policy which allows players to wear colorful sneakers during the game as a way of expressing their individuality (Flores, 2015). On the other hand, professional athletes show off a muscular body and tremendous power on the court. For instance, the NBA superstar, LeBron James is widely known for his incredible workout and physical strength in spite of his old age as a player (Davis, 2018). College student athletes who have their own sports role model are likely to envy such a strong physique and train the body in order to make it strong.

This newly-developed sports role model scale can help both scholars and practitioners comprehensively understand and assess the eight dimensions of the sports role model instrument. For example, sport marketing researchers can utilize the instrument to examine how each dimension influences admirers' purchase intentions for their own sports role model's merchandise and endorsement products, as well as for attendance at (or watching) games. Furthermore, the comprehensive sports role model instrument can allow professional sport league administrators to investigate which aspects of sports role models are perceived to be good or bad by collegiate student athletes. Based on the scores measured by the sports role model scale, administrators could educate and improve upon athletes' weak points. Such systematic evaluation and education on the multiple domains of sports role model behavior can help professional athletes become better role models, while improving the reputation of professional sport leagues.

Professional sport league administrators and sporting goods company marketers have utilized professional athletes for various purposes, such as regular/playoff season promotion videos, back-to-school campaigns, community service events, fan meetings, sports clinics, public service announcements, and endorsement commercials, etc. However, the selection of an appropriate athlete seems to be made intuitively rather than scientifically. This multi-dimensional sports role model instrument can provide the practitioners with scientific evidence to help them choose the most effective sports role models on the basis of relevant dimension scores. For example, it is suggested that league administrators refer to professionalism dimension scores in order to select a proper sports role model when they make films to promote a good work ethic as a way of encouraging young student athletes to study and work hard. It is also suggested that practitioners consider personality dimension scores when they plan to hold fan meeting events. Furthermore, this study suggests that the athletic performance dimension scores be used when choosing athletes who appear in promotional videos for regular season/playoff games. The community service sub-scale could be a good measure for league administrators looking for a sports role model who is eligible to conduct a campaign of community service in order to inspire social consciousness among young people.

Additionally, the current study suggests that sporting goods company marketers who target a young fashion-conscious group could consider game outfit dimension scores as a way of finding an appealing endorser. Moreover, sports drink or supplement company marketers who plan to sell their products to young consumers who want to build up a strong physique could refer to physical strength dimension scores. Finally, administrators creating public service advertisements to educate and prevent immature student athletes from engaging in immoral/criminal activities, such as premarital sex, abortion, smoking, drunk-driving, drug use, and domestic violence, could pay attention to athletes who receive high scores on the morality dimension.

Although this study's findings are significant, it has a limitation. Due to the logistical difficulty of using a random sampling technique for data collection, convenience sampling was used for the sample of South Korean university student athletes. Therefore, the samples utilized may not be representative of the larger population. Thus, the results obtained from the study should be interpreted with caution. In order to enhance external validity, a probability sampling method should be planned and implemented that would increase the sample size in broader geographic regions and other countries.

\section{REFERENCES}

Adair, D. (2015, December 18). Athletes of influence. Bounce of the ball. Retrieved from https://theconversation.com/athletes-ofinfluence-the-role-model-refrain-in-sport-52569

Addis, A. (1996). Role models and the politics of recognition. University of Pennsylvania Law Review, 144(4), 1377-1468.

Arai, A, Ko, Y, \& Kaplanidou, K. (2013). Athlete brand image: scale development and model test. European Sport Management, 13(4), 383-403.

Assibey-Mensah, G. O. (1997). Role models and youth development: Evidence and lessons from the perceptions of African-American male youth. The Western Journal of Black Studies, 21(4), 242-251. 
Badenhausen, K. (2018, June 5). The world's 100 highest-paid athletes 2018. Forbes. Retrieved from https://www.forbes.com/sites/kurtbadenhausen/2018/06/05/the-worlds-100-highest-paid-athletes-2018-behind-thenumbers/\#10caceab4dd0

Bandura, A. (1977). Social learning theory. Englewood Cliffs, N.J.: Prentice Hall.

Biskup, C., \& Pfister, G. (1999). I would like to be like her/him: Are athletes role-models for boys and girls? European Physical Education Review, 5(3), 199-218.

Bricheno, P., \& Thornton, M. (2007). Role model, hero or champion? Children's views about role models. Educational Research, 49(4), 383-396.

Burch, H. M., \& Murray, J. B. (1999). An essay on athletes role models, their involvement in charities, and considerations in starting a private foundation. Sports Lawyers Journal, 6, 249-271.

Bush, A. J., Martin, C. A., \& Bush, V. D. (2004). Sports celebrity influence on the behavioral intentions of generation Y. Journal of Advertising Research, 44(1), 108-118.

Clark, P. W., Martin, C. A., \& Bush, A. J. (2001). The effect of role model influence on adolescents' materialism and marketplace knowledge. Journal of Marketing Theory and Practice, 9(4), 27-36.

Coakley, J. J. (2001). Sport in society: Issues and controversies. New York: McGraw-Hill.

Davis, S. (2018, June 3). LeBron James takes immaculate care of his body, and the NBA world is in awe of it. Business Insider. Retrieved from https://www.businessinsider.com/lebron-james-body-care-workouts-diet-insane-2017-10

DeVellis, F. (2012). Scale development: Theory and applications. Thousand Oaks, CA: Sage.

Eisenband, J. (2010, September 3). 2010's Most Loved Athletes. Bleacher Report. Retrieved from https://bleacherreport.com/articles/450276-2010s-most-loved-athletes\#slide0

Ellis, C. (2018, February 23). Kevin Durant commits $\$ 10$ million to Prince George's County public schools. NBC Sports. Retrieved from https://www.nbcsports.com/washington/wizards/kevin-durant-commits-10-million-prince-georges-county-public-schools

Feezell, R. (2005). Celebrated athletes, moral exemplars, and lusory objects. Journal of the Philosophy of Sport, 32(1), 20-35.

Fleming, S., Hardman, A., Jones, C., \& Sheridan, H. (2005). Role models among elite young male rugby league players in Britain. European Physical Education Review, 11(1), 51-70.

Flores, G. (2015, February 23). New rules: breaking down the NBA's sneaker policy. Sole Collector. Retrieved from https://solecollector.com/news/2015/02/new-rules-breaking-down-the-nba-s-sneaker-policy

Freedman-Doan, C., \& Eccles, J. S. (1996). Where have you gone Joe Dimaggio? An examination of adolescent's heroes and identity formation. Paper presented at the Sixth Society for Research on Adolescence, Boston, MA.

Funk, D.C., Ridinger, L. L., \& Moorman, A. M. (2003). Understanding consumer support: Extending the sport interest inventory (SII) to examine individual differences among women's professional sport consumers. Sport Management Review, 6, 1-32.

Giuliano, T. A. Turner, K. L., Lundquist, J. C., \& Knight, J. L. (2007). Gender and the selection of public athletic role models. Journal of Sport Behavior, 30(2), 161-198.

Globus, S. (1998). Athletes as role models. Current Health, 24(6), 25-28.

Guest, A. M., \& Cox, S. (2009). Using athletes as role models? Conceptual and empirical perspectives from a sample of elite women soccer players. International Journal of Sports Science \& Coaching, 4(4), 567-581.

Gorsuch, R. L. (1983). Factor analysis. Hillsdale, NJ: Erlbaum.

Harris, J. (1994). Athletes and the American hero dilemma. Champaign, IL: Human Kinetics.

$\mathrm{Hu}, \mathrm{L} .$, \& Bentler, P. (1999). Cutoff criteria for fit indexes in covariance structure analysis: Conventional criteria versus new alternatives. Structural Equation Modeling, 6(1), 1-55.

Kell, J. (2016, March 19). Why Nike, Adidas are turning to celebrities in 2016. Fortune. Retrieved from http://fortune.com/2016/03/19/nike-adidas-kevin-hart-kanye

Kellner, D. (1996). Sports, media culture, and race: Some reflections on Michael Jordan. Sociology of Sport Journal, 13, $458-467$.

Kim, Y., \& Trail, G. (2010). Constraint and motivators: A new model to explain sport consumer behavior. Journal of Sport Management, 24(2), 190-210.

Kohlstrung, L. (2016). Characteristics of good role models in sports and social life. Retrieved from https://essay.utwente.nl/69918/1/Kohlstrung_BA_BMS.pdf

May, B. (2009). The good and bad of it all: Professional black male basketball players as role models for young black male basketball players. Sociology of Sport Journal, 26, 443-461.

Mclendon, S. (2016, January 3). Top 10 worst sports role models of 2015. Movie TV Tech Geeks. Retrieved from https://movietvtechgeeks.com/top-10-worst-sports-role-models-of-2015

Neemann, J., \& Harter, S. (2012). Self-perception profile for college. Department of Psychology. University of Denver.

Netemeyer, R. G., Bearden, W. O., \& Sughash, S. (2003). Scaling procedures: Issues and applications. Thousand Oaks, CA: Sage.

O'Brien, G. (2015, March 4). Young Michael Jordan. GQ. Retrieved from https://www.gq.com/story/michael-jordan

Pulley, B. (2001, March 19). Top of the lineup. Derek Jeter is must-see TV. Forbes. Retrieved from https://www.forbes.com/forbes/2001/0319/130.html\#75c062d3586c

Rich, G. A. (1997). The sales manager as a role model: Effects on trust, job satisfaction, and performance of salespeople. Journal of the Academy of Marketing Science, 25(4), 319-328.

Rojek, C. (2006). Sports celebrity and the civilizing process. Sport in Society, 9, 674-690.

Schumacker, R. E., \& Lomax, R. G. (2010). A Beginner's Guide to Structural Equation Modeling (3 ${ }^{\text {rd }}$ ed.). Mahwah, NJ: Lawrence Erbaum Associates. 
Smoll, F. (2015, April 20). Are athletes good role models? Psychology Today.

Retrieved from https://www.psychologytoday.com/us/blog/coaching-and-parenting-young-athletes/201504/are-athletes-goodrole-models

Stern, M. (2016). Kobe Bryant's disturbing rape case. Daily Beast. Retrieved from https://www.thedailybeast.com/kobe-bryantsdisturbing-rape-case-the-dna-evidence-the-accusers-story-and-the-half-confession

Strudler, K. A. (2000). The mass mediated sports hero as a role model for adolescent males: Measuring self-concept congruity with perceived image of the hero to predict role

Terrill, M. (2012, November 30). Chanho Park holds mark for most wins by Asian pitcher in MLB history. Rant Sports. Retrieved from http://www.rantsports.com/mlb/2012/11/30/chan-ho-park-holds-mark-for-most-wins-by-asian-pitcher-in-mlb-history/

Tuchman, G., \& Cabell, B. (2003, December 16). Kobe Bryant charged with sexual assault. CNN.com. Retrieved from http://www.cnn.com/2003/LAW/07/18/kobe.bryant

Vescio, J., Wilde, K., \& Crosswhite, J. J. (2005). Profiling sport role models to enhance initiatives for adolescent girls in physical education and sport. European Physical Education Review, 11(2), 153-170.

Williams, L. (2017, September 11). Why do athletes make good role models? Live Strong.

Retrieved from https://www.livestrong.com/article/374758-why-do-athletes-make-good-role-models

Wilson, B., \& Sparks, R. (1996). It's gotta be the shoes: Youth, race, and sneaker commercials. Sociology of Sport Journal, 13(4), 398427.

\section{Author Information}

Doyeop Kim, Ph.D., Corresponding Author

(1) https://orcid.org/0000-0002-7933-9183

Assistant Professor

Department of Education

Louisiana State University, Alexandria, LA, USA

@ doyeopkim1976@gmail.com

Minkil Kim, Ph.D.

(1) https://orcid.org/0000-0002-5619-5412

Associate Professor

School of Hospitality, Sport \& Tourism Management

College of Business, Troy University, AL, USA

@mkim95145@troy.edu

Anthony Dixon, Ph.D.

(1) https://orcid.org/0000-0003-3556-8678

Professor \& Director

School of Hospitality, Sport \& Tourism Management

College of Business, Troy University, AL, USA

@awdixon@troy.edu
Giyong Koo, Ph.D.

(1) https://orcid.org/0000-0001-5411-9662

Professor \& Sport Management Doctoral Coordinator

School of Hospitality, Sport \& Tourism Management

College of Business, Troy University, AL, USA

@ivkoo@troy.edu

Stephen Shin, Ph.D.

(1) https://orcid.org/0000-0002-9647-5208

Associate Professor, Department of Sport Administration

College of Liberal Arts \& Social Sciences

Belmont University, TN, USA

@ Stephen.shin@belmont.edu

Conflict of Interest: The authors declare that the research was conducted in the absence of any commercial or financial relationship that could be constructed as a potential conflict of interest.

Publisher's Note: All claims expressed in this article are solely those of the authors and do not necessarily represent those of their affiliated organizations, or those of the publisher, the editors and reviewers. Any product that may be evaluated in this article, or claim that may be made by its manufacturer, is not guaranteed or endorsed by the publisher.

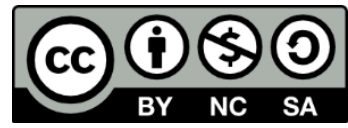

Copyright (C) 2020-2021. This work is licensed under a CC BY-NC-SA 4.0 International license. This is an open access article distributed under the Creative Commons Attribution License which permits unrestricted use, distribution, and reproduction in any medium, provided the original work is properly cited. 